V. S. Vasilyeva

\title{
Structural and spatial priorities of socio-economic development and their implementation in the territory of the Rostov region (Russian Federation)
}

\section{KEYWORDS}

agro-industrial parks;

public-private partnership;

poles of growth;

priorities of socio-economic development;

Rostov Region;

strategic project initiatives;

structural and spatial priorities

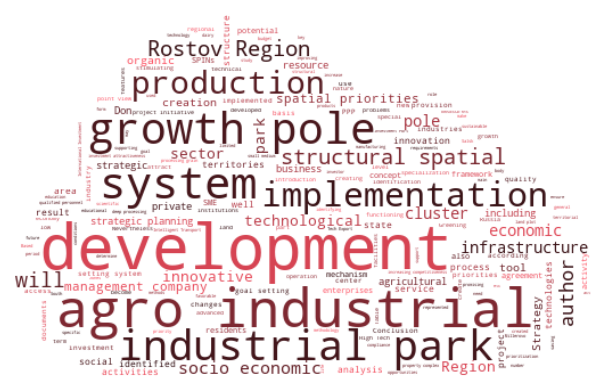

Word Cloud Generated by:

https://wordscloud.pythonanywhere.com/

\section{ABSTRACT}

Proper strategic management of regional socio-economic development is impossible without strategic planning that provides a full analysis of the current development of the system and the formation of a desired image of its future development and the mechanisms for its implementation. An element of the goal-setting system in the process of strategic planning is the identification of priorities for socio-economic development that allow for more efficient use of limited budget resources. It has been offered to focus on structural-spatial type priorities, providing for the interconnection of structural and spatial changes in the system and an opportunity to solve restructuring problems by stimulating territorial development and, conversely, developing territories through support for specific sectors of the economy.

The methods of logical, comparative and economic analysis, tabular and graphical data visualization have been used. The structural and spatial priorities of the socio-economic development of the Rostov Region have been highlighted and the growth poles and strategic design initiatives of a structural-spatial nature defined in the Strategy for the Socio-Economic Development of the Rostov Region for the period up to 2030 have been systematized from the point of view of implementing the identified priorities. This, in turn, made it possible to consider the opportunity of realizing structural and spatial priorities within the framework of measures enshrined in the strategic planning documents of the Rostov Region using the example of agroindustrial growth poles, to propose an additional set of measures to implement the spatial development tool - to prepare and create agroindustrial parks in agro-industrial growth poles of the Rostov Region using the mechanism of public-private partnership.

Vasilyeva, V. S. (2020). Structural and spatial priorities of socioeconomic development and their implementation in the territory of the Rostov region (Russian Federation). Economic consultant, 30 (2), 25-35. doi: 10.46224/ecoc.2020.2.3 


\section{INTRODUCTION}

$\ln$ theory and practice, strategic planning is an integral part of the strategic management process. It includes an analysis of the system, its weaknesses and promising areas of development, identification of images of the desired future in the form of a goal-setting system, the selection of alternative development options, and the choice of a mechanism for achieving the desired image of the system's future. Along with the mission, goals, and objectives identified during goal setting, the system's development priorities play an important role. There are different approaches to prioritization in the academic literature: as the most urgent problems, or as the most promising areas of development of the system. The author proposes to address priority from a pragmatic point of view in its role in the system of strategic planning considering such factors as the accepted concept of development that determines the generally accepted belief system, and the technological system that determines the prospects of the technological development system: the priority of socioeconomic development is the direction of development, defined in the course of strategic planning as significant in accordance with the adopted concept of development and the features of the current technological paradigm, for the implementation of which some activities will be worked out and fixed in strategic planning documents, budget resources will be allocated, and tools for attracting private investment for its implementation will be developed to solve the most acute problems of the socio-economic system, which will ultimately improve the quality of people's living standards. Within the framework of strategic planning of regional development, the importance of prioritization is determined by the special limited budget resources for the implementation of planned activities, which increases the need to specify the most significant areas of development and related activities of medium-term state programs [1].

A special role belongs to strategic priorities of a structural and spatial nature, reflecting the interdependence of the process of economic restructuring and spatial changes: the development rate of a particular industry may depend on the development of a specific territory (for example, differentiation and linking the level of agricultural development to the quality of rural territories), while the restructuring process may have influence on the development of a territory (cases of depression of single-industry towns). Nevertheless, prioritization is recommended [18], but is not always implemented in practice in strategic documents, while the topic of structural and spatial priorities remains poorly developed.

The aim of this work is to highlight the system of structural and spatial priorities of the socio-economic development of the Rostov Region, as well as discuss mechanisms for their implementation. 


\section{MATERIALS AND METHODS}

The methods of logical, comparative and economic analysis, tabular and graphical data visualization were used. The study is based on the provisions of the concept of strategic planning [10], the theory of regional economics [11], and the concept of growth poles [9].

The statistical collections of Rosstat [15] and Rostovstat [16], as well as the analysis results reflected in the Strategy for the Socio-Economic Development of the Rostov Region for the period up to 2030 (hereinafter referred to as "Strategy-2030") [4], were used as an empirical and factual base.

\section{RESULTS}

The author offers a general methodology for identifying the structural and spatial priorities of a region (Figure 1), including an analysis of the region's socio-economic system using various methods [3], the need for coordination with the federal goal-setting system, development concept, and technological paradigm. They become the basis for identifying the system of goals and objectives of Strategy-2030 and the identification of strategic priorities. An analysis of the region's spatial structure and the point of contact of the expected structural changes in the economy and the features, problems and development potential of the territories allows highlighting the structural and spatial development priorities. The formed goal-setting system becomes the basis for the development of specific activities and tools for its implementation. The whole process is carried out in accordance with the principles highlighted in [17, p. 20].

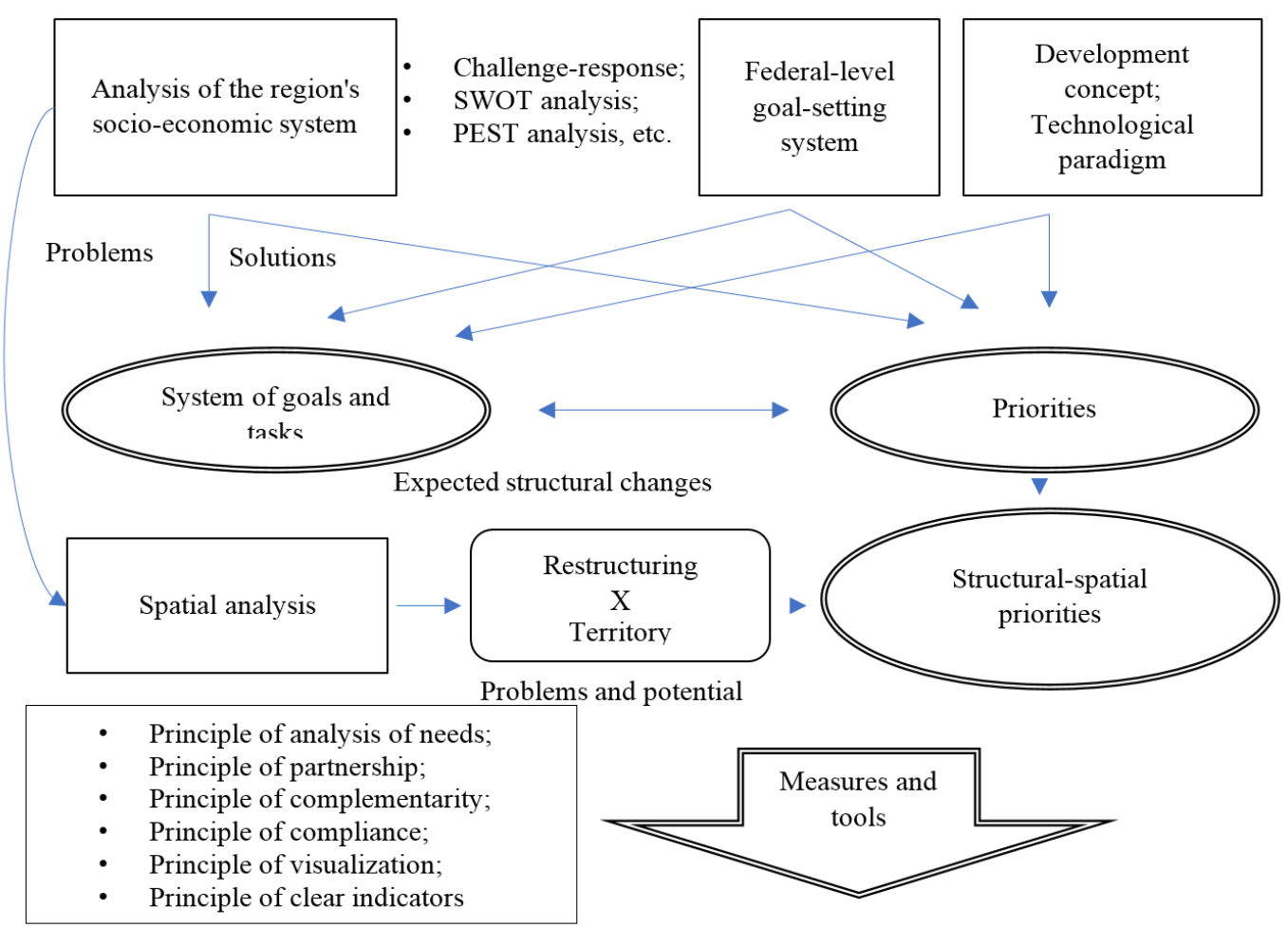

Figure 1 General methodology for identifying structural and spatial priorities [Compiled by the author] 
Also, to identify the structural and spatial priorities, the author's matrix methodological approach was used, implying an analysis of the region's socio-economic development, the global sustainable development goals defined by the UN, and the goal-setting system of Strategy-2030 [21]. According to the described methodology, on the basis of official statistics and the provisions of Strategy-2030, the author identified the key development problems of the Rostov Region related to the deterioration of the material and technical base, low availability of demanded qualified personnel, differentiation of spatial development, inconsistency of the sectoral investment structure with the industrial needs and with the structure of gross added value, low incomes of some categories of citizens, low socio-economic activity of some population groups, insufficient interaction of business, science and education, etc., as well as features of the spatial structure, including a support frame in the form of a system of growth poles and the presence of a system of clusters, opportunities and prospects for regional development.

Based on them and taking into account the principles of sustainable development as the stated conceptual approach of strategic planning for the current planning period, the following structural and spatial priorities were identified:

1. Greening and digitalization of the manufacturing sector and increasing the competitiveness of regional industries, considering spatial tools as advanced institutions for the development of technology. Moreover, greening has two key areas: resource-saving technologies and adoptions that reduce the negative impact on the environment. As a result - increasing competitiveness via saving resources and using a green brand; reduction of anthropogenic impact on the environment.

2. Equalizing the center and the periphery in access to social services by enhancing their provision and accessibility at the growth poles.

3. Territorial implementation of the growth poles as a supporting framework of the region's spatial tools to increase the investment attractiveness of the poles, attract resources, stimulate innovative and economic, and as a result, social development.

4. Stimulating the innovative activity of organizations and enterprises, the interaction of business, educational and scientific institutions in terms of training demanded qualified personnel, development and implementation of innovative technologies, a platform for which can be created through the implementation of spatial policy instruments. As a result - increasing the efficiency of business functioning, its competitiveness in the interregional and world arena.

The implementation of the identified structural and spatial priorities is considered from the point of view of the strategic project initiatives identified in Strategy-2030, as well as the system of growth poles as a supporting territorial framework for the socio-economic development of the region.

Strategic project initiatives (hereinafter referred to as SPINs) are the main tool for structural changes in the region's socio-economic system in Strategy-2030. The author selected SPINs of a structural and spatial nature, that is, their implementation affects changes in the structure of the economy and territorial development and can be associated with the implementation of spatial development tools (the implementation of a system of growth poles, the creation and 
functioning of clusters, industrial parks, special economic zones, territories of advanced socioeconomic development): in the agricultural sector - "Rostov Region - Agro-Industrial Pole of Russia"; in industry - "New Industrialization of the Don"; in small and medium business - "Cluster of Industrial SMEs"; in investment - "International Investment Port"; in innovation "The Don Valley of Innovation Development"; in export - "The South Pole of High-Tech Export Growth"; in tourism - "The Hospitable Don"; in transport - "Intelligent Transport System of the Rostov Region"; in the resettlement system - "The System of Growth Poles of the Rostov Region".

The author has proposed a table reflecting the correspondence of structural-spatial SPINs to structural-spatial priorities and key growth poles in which they will be implemented (Table 1).

Table 1

Growth poles of the Rostov Region and strategic project initiatives of a structural and spatial nature implemented in their territories [Compiled by the author]

\begin{tabular}{|c|c|c|c|c|c|c|c|c|}
\hline \multirow{3}{*}{$\begin{array}{c}\text { Structural-spatial } \\
\text { priorities }\end{array}$} & \multirow{3}{*}{$\begin{array}{c}\text { Structural-spatial } \\
\text { SPINs }\end{array}$} & \multicolumn{7}{|c|}{ Growth poles } \\
\hline & & \multirow{2}{*}{$\begin{array}{c}\begin{array}{c}\text { Innovative } \\
\text { and } \\
\text { technological }\end{array} \\
\begin{array}{c}\text { Rostov } \\
\text { aglomeration }\end{array}\end{array}$} & \multicolumn{3}{|c|}{ Industrial } & \multicolumn{3}{|c|}{ Agro-industrial } \\
\hline & & & $\begin{array}{l}\text { Volga- } \\
\text { Don }\end{array}$ & $\begin{array}{c}\text { East- } \\
\text { Donbass }\end{array}$ & Taganrog & Millerovo & Morozovsk & Salsk \\
\hline \multirow{2}{*}{$\begin{array}{l}\text { Greening and } \\
\text { increasing the } \\
\text { competitiveness of } \\
\text { manufacturing }\end{array}$} & $\begin{array}{c}\text { New } \\
\text { Industrialization } \\
\text { of the Don }\end{array}$ & + & + & + & + & & & \\
\hline & $\begin{array}{l}\text { Rostov Region - } \\
\text { Agro-Industrial } \\
\text { Pole of Russia }\end{array}$ & & & & & + & + & + \\
\hline \multirow{2}{*}{$\begin{array}{l}\text { Equalizing the } \\
\text { center and the } \\
\text { periphery in access } \\
\text { to social services }\end{array}$} & $\begin{array}{c}\text { The Hospitable } \\
\text { Don }\end{array}$ & + & & + & + & & & \\
\hline & $\begin{array}{c}\text { Intelligent } \\
\text { Transport System } \\
\text { of the Rostov } \\
\text { Region }\end{array}$ & + & + & + & + & + & + & + \\
\hline \multirow{3}{*}{$\begin{array}{l}\text { Implementation of } \\
\text { spatial development } \\
\text { tools to attract } \\
\text { investment }\end{array}$} & $\begin{array}{c}\text { Cluster of } \\
\text { Industrial SMEs }\end{array}$ & + & + & + & + & + & + & + \\
\hline & $\begin{array}{c}\text { International } \\
\text { investment port }\end{array}$ & + & + & + & + & + & + & + \\
\hline & $\begin{array}{l}\text { The System of } \\
\text { Growth Poles of } \\
\text { the Rostov Region }\end{array}$ & + & + & + & + & + & + & + \\
\hline \multirow{2}{*}{$\begin{array}{l}\text { Cooperation of } \\
\text { business, education } \\
\text { and science }\end{array}$} & $\begin{array}{l}\text { The Don Valley } \\
\text { of Innovation } \\
\text { Development }\end{array}$ & + & & & & & & \\
\hline & $\begin{array}{l}\text { The South Pole of } \\
\text { High-Tech Export } \\
\text { Growth }\end{array}$ & + & + & + & + & + & + & + \\
\hline
\end{tabular}

The specialization of growth poles was identified on the basis of the structure of their economy, as well as on the basis of infrastructure development. So, in the Rostov agglomeration, an innovative technological infrastructure is developed, and high-tech industries and the service sector are actively developing. The infrastructure of industrial and agro-industrial poles is 
aimed at ensuring industrial and agro-industrial activity, respectively, and is not so innovative in nature (in agro-industrial poles, innovation is represented only by business incubators, and in the Morozovsky District there are no higher education institutions at all). Nevertheless, the potential of the growth poles is sufficient to act as centers in the zones of its influence and advanced territories for the development of the respective industries in the region.

\section{RESULTS AND DISCUSSION}

The author offers to focus on agro-industrial growth poles as first-level poles for the development of a life quality infrastructure. Each of them has its own characteristics, which can become priorities for their development. In addition, the agro-industrial growth poles have agro-industrial specialization, which is one of the priority areas for the development of the "granary of Russia".

The Millerovo agro-industrial growth pole is the center of the cluster for the deep processing of grain, and its enterprises are also part of the Don dairy products cluster. It has the most favorable position in terms of being on federal highways and railways [6].

The Morozovsk growth pole is characterized by the prevalence of the sector of small and medium-sized enterprises, which almost forced out large players. In the agricultural sector, 2/3 of the output is crop production, while livestock production, represented mainly by peasant (household) farms and private subsidiary farms, has limited sales opportunities, still its potential has not yet been exhausted [7]. It is worth noting that according to Orekhova and Kislitsyn, small business does not always act as a driver of structural changes in the economy [13]. Nevertheless, in Strategy-2030 a bet was placed on the SME sector, as evidenced by, among other things, the strategic project initiative "Cluster of Industrial SMEs".

The Salsk growth pole can be called the most developed agro-industrial growth pole, which has the most extensive social infrastructure (however, with some uncovered areas), characterized by the implementation of a number of investment projects in deep processing of grain and meat and dairy farming, in other industries with export potential. Innovation activity mainly falls on small and medium-sized businesses [8].

According to Table 1, the following structural-spatial SPINs are implemented in agroindustrial growth poles: "Rostov Region - Agro-Industrial Pole of Russia", "Intelligent Transport System of the Rostov Region", "Cluster of Industrial SMEs", "International Investment Port", "The South Pole of High-Tech Export Growth", "The System of Growth Poles of the Rostov Region". In general, the measures of the Action Plan for the implementation of Strategy-2030 [5] and existing state programs [14] ensure the implementation of the opportunities and parameters set by the SPINs.

The main spatial tools indicated in the actions are clusters and agro-industrial parks. The author believes that among spatial development tools, they are the least costly from the point of view of the state budget: special economic zones and territories of advanced socio-economic 
development provide their residents with benefits and preferences, while clusters involve the investment costs of private individuals, and agro-industrial parks suggest the possibility of applying the mechanism of public-private partnership (municipal-private partnership) with minimization of costs of the state via the form of land provision. Land development, creation of a property complex, providing access to engineering networks in this case can be realized by private investors. Unfortunately, the agro-industrial sector does not have such an investment attractiveness as the manufacturing sector, the service sector and the digital technologies. Nevertheless, the creation of primary facilities and support from the park management company reduce the risks of the first stages of operation for new industries and allows focusing directly on the production process, including by stimulating innovative activity, the level of which is relatively low in the agro-industrial sector [12]. Therefore, it is advisable to apply the PPP mechanism with sharing risks and realizing the advantages of both parties to attract private investment resources.

Measures to create agro-industrial parks in strategic planning documents are limited to assessing the financial and economic model for creating agro-industrial parks with preferences for residents, creating economic and organizational conditions for the leading universities of the region to implement the functions of the anchor structure of technology parks (provided that at least one of the created agro-industrial parks is technological by type). The author proposes to add a number of specific measures preceding the period of the park's full operation, taking into account the use of the PPP mechanism as a way of stimulating the introduction of modern technologies in the production process [20, p. 21]:

- Identification of a management company (it may be represented by an investor - a private partner of a PPP). It can participate in all activities of the preparatory phase.

- Monitoring the interest of economic entities in the creation of an agro-industrial park. They can be both direct producers and scientific and educational institutions and other enterprises that make up the innovative infrastructure of the park, as well as service entities that ensure the use of innovative technologies in agro-industrial production. An analysis of the existing system of industrial parks, the socio-economic and spatial system of the region, the study of all aspects of the functioning and potential of the agroindustrial park project.

- Improving the regulatory framework governing the activities of agro-industrial parks in the Rostov Region.

- Based on the monitoring results, identification of the necessary technical characteristics of the agro-industrial park, creation of a full-fledged project.

- Selection of a land plot owned by the state (a municipality), corresponding to the requirements for the parks.

- Conducting a tender and drawing up an agreement on PPP to create a property complex on the land plot to ensure the functioning of an agro-industrial park on it.

- Submission of the application to the responsible body of the Rostov Region by the initiator (state/municipal body, initiative group, including management company) for 
the creation of an agro-industrial park with the submission of the feasibility study of the project and a package of supporting documents. Upon approval, the documentation is handed over to the Government of the Rostov Region to make a decision on the creation of the park to be confirmed by a normative legal act.

- Conclusion of an agreement on the implementation of the project to create and develop a park between the management company and the responsible body of the Rostov Region. Further, it will coordinate the development and operation of the agro-industrial park.

- Concluding agreements and carrying out the technological connection to utility networks, providing access to industrial and technological infrastructure. Construction and preparation of premises for production activities by future residents. Carrying out the necessary work to bring the permitted uses of the land into compliance with its intended use within the framework of the agro-industrial park (but agricultural land for use in agricultural production cannot exceed $25 \%$ of the area of an agro-industrial park).

- Conclusion of preliminary agreements between the management company of the industrial park and its potential residents.

- Conclusion of an agreement and transfer of rights to operate a land plot and property complex of the management company.

- The management company submits an application and a package of documents to confirm the compliance of the agro-industrial park and the management company with the requirements for the industrial park and the management company of an industrial park in order to apply incentive measures in the industry. Compliance must be verified every 5 years.

- Conclusion of agreements between the management company and residents and the beginning of the direct operation of the park.

It is worth noting that, according to the law, the PPP mechanism can be implemented in the social sphere, in the provision of ICT services, infrastructure, etc., as well as objects and property complexes in the industry [2], thereby limiting the specialization of the planned agroindustrial park to the processing of agricultural raw stock. The features of agro-industrial growth poles determine that in the Morozovsky District, the main residents of the park will be SMEs; in Millerovo and Salsk - enterprises for the deep processing of grain and for the processing of meat and dairy products, including those that are part of the clusters. The opportunity of organizing a technology park with the involvement of leading agricultural and technical research and educational centers in the innovation infrastructure - DonSAU, DSTU, etc. should also be noted.

Also, according to the author, when creating projects for agro-industrial parks, an alternative to a specialization in organic production should be worked out. This direction is considered promising from the point of view of the concept of sustainable development, but organic production is inferior to traditional in a number of ways, including in terms of economic profitability. In addition, obstacles limiting the green modernization of production facilities (including the political, economic, informational factors, the level of business activity, the appropriate regulatory framework, the institutional support for innovative enterprises, the 
availability of financial, scientific, technical, technological and other resources, the government interest in modernization [19]) should be assessed and overcome. Creating favorable conditions for the development of organic production, certification and branding of organic products by the state, improving and making organic production commercially profitable through the development and implementation of organic innovations can make it more attractive for investors. Organic food production will meet the demand for organic agricultural raw stock, thus stimulating its production. The introduction of environmentally friendly and resourcesaving technologies into production will have a beneficial effect on the environmental processes. This also refers to the creation of the infrastructure of an industrial park as a whole: all environmental safety requirements must be met. Ultimately, the consumption of organic food has a beneficial effect on public health and quality of life.

\section{CONCLUSION}

The creation of agro-industrial parks at agro-industrial growth poles will facilitate the implementation of all the structural and spatial priorities identified by the author: production sites will be created for new facilities, which will provide favorable conditions for the implementation of investment projects and the introduction of modern technologies, including as part of the greening process. The development of production facilities in the growth poles will not only increase investment attractiveness but also create new jobs and help attract and retain qualified personnel. Population growth, in turn, will become an incentive for the development of social services and improving the quality of life. The peculiarity of the agroindustrial poles is that their development will spread to a greater extent to the surrounding rural territories, increasing their access to social infrastructure and other benefits.

\section{REFERENCES}

1. Federal Act No. 172-FZ dated (as amended on July 18, 2019) "On Strategic Planning in the Russian Federation". (2014, June 28). Retrieved January 23, 2020, from http://www. consultant.ru/cons/cgi/online.cgi? req $=$ doc \&base $=\mathrm{LAW} \& \mathrm{n}=329362 \& \mathrm{fld}=134 \& \mathrm{dst}=100$ 009,0\&rnd=0.9612583527063561\#07252657297050626

2. Federal Act of the Russian Federation No. 224-FZ "On Public-Private Partnerships, Municipal-Private Partnerships in the Russian Federation and Amending Particular Legislative Acts of the Russian Federation". (2015, July 13). Retrieved March 18, 2020, from http://www.consultant.ru/cons/cgi/online.cgi? req=doc\&base=LAW\&n=330160\&fl $\mathrm{d}=134 \& \mathrm{dst}=100009,0 \& \mathrm{rnd}=0.4203955017914949 \# 075376046416113$

3. Order of the Ministry of Economic Development of Russia No. 132 (as amended on September 7, 2018) "On Approval of the Methodological Recommendations for the 
Development and Adjustment of the Socio-Economic Development Strategy of a Region of the Russian Federation and the Action Plan for Its Implementation". (2017, March 23). Retrieved March 23, 2020, from http://www.consultant.ru/document/cons_doc_ LAW_214725/e2a7dc65b5742f224b8aa5ca26a813ee33bd1b5b/

4. Decree of the Government of Rostov Region No. 864 "On Approval of the Strategy for the Socio-Economic Development of the Rostov Region for the Period up to 2030". (2018, December 26). Retrieved October 23, 2019, from http://old.donland.ru/documents/Obutverzhdenii-Strategii-socialno-ehkonomicheskogo-razvitiya-Rostovskojj-oblasti-naperiod-do-2030-goda?pageid=128483\&mid=134977\&itemld=28439

5. Decree of the Government of Rostov Region No. 885 "On the Approval of the Action Plan for the Implementation of the Strategy for the Socio-Economic Development of the Rostov Region for the Period up to 2030". (2018, December 29). Retrieved March 21, 2020, from https://www.donland.ru/documents/10047/

6. Decision of the Meeting of Deputies of the Millerovsky District No. 383 "On approval of the Strategy for the socio-economic development of the Millerovsky District of the Rostov Region until 2030". (2018, December 27). Retrieved March 10, 2020, from http:// millerovoland.ru/index.php?option=com_content \&view=article\&id=8534:strategiyasotsialno-ekonomicheskogo-razvitiya-millerovskogo-rajona\&catid=339:materialy-2019

7. Decision of the Meeting of Deputies of the Morozovsky District No. 376 "On Approval of the Strategy for the Socio-Economic Development of the Morozovsky District until 2030". (2018, September 18). Retrieved March 14, 2020, from https://morozovsky. donland.ru/documents/active/2022/

8. Decision of the Meeting of Deputies of the Salsky District dated December 25, 2018 No. 253 "On the Strategy for the Socio-Economic Development of the Salsky District of the Rostov Region until 2030". (2018, December 25). Retrieved March 14, 2020, from http://www.salsk.org/index.php?option=com_content\&view=article\&id=2946:strategi ya-razvitiya-2030\&catid=92:tselevye-programmy

9. Abdullaev, R.A., \& Mishchenko, K.N. (2017). A Study of the Theoretical and Methodological Foundations of the Concept of Territorial Development of a Region and the Formation of a System of Growth Poles of the Rostov Region. Regional Economy: Theory and Practice, 15(5(440)), 802-813.

10. Kareva, A.V. (2014). The Strategic Planning System as the Basis for Sustainable Regional Development Management. University Herald, 16, 120-125.

11.Lapaev, S.P., \& Zatsarinina, Yu.V. (2017). Theoretical Foundations of the Balanced Development of Regional Economies. Intelligence. Innovation. Investments, 9, 31-34.

12. Neganova, V.P., \& Dudnik, A.V. (2019). Readiness to Innovations in a Regional AgroIndustrial Sector as a Subjective Factor of Innovative Activity. Economy of the Region, 15(3), 880-892.

13. Orekhova, S.V., \& Kislitsyn, E.V. (2019). Small Business and Structural Changes in Industry. Terra economicus, 17(4), 129-147. 
14.Programs. (n.d.). Official portal of the Government of Rostov Region. Retrieved March 29, 2020, from https://www.donland.ru/activity/14/

15. Regions of Russia. Socio-Economic Indicators - 2019. (2019). Retrieved February 10, 2020, from https://gks.ru/bgd/regl/b19_14p/Main.htm

16. Rostovstat. (2019). Rostov Region - Movement towards the Goals of Sustainable Development. Information and Analytical Materials. Rostov-on-Don. (p. 202).

17. Ostropilova, V.V. (Ed.). (2009). Strategic Priorities of Regional Development: From Theory to the Principles of a Single Socio-Economic Space. St. Petersburg: Nauka. (p. 448).

18. Shekhovtsov, R.V., Abdullaev, R.A., \& Astakhova, O.Yu. (2015). Organizational and Methodological Strategic Planning Decisions in the Regional Economy (Case Study of the Rostov Region. In Logistics in the Resource Portfolio of Import-Substituting Industrialization: Anti-Crisis Growth and Development Strategies under Conditions of Sanctions: Materials of the International Scientific and Practical XI South Russian Logistics Forum (pp. 513-521).

19. Shkarupa, E.V. (2015). Management of Environmental Modernization of the SocioEconomic Development of the Region. Economic Journal-XXI, 7-8-2, 57-60.

20. Tikhonova, A., Melnikova, N., \& Vishnevskaya, N. (2018). Readiness of Russian Regions to Digitize the Economy. Economic Journal-XXI, 11-12(174), 16-21.

21. Vasilyeva, V.S. (2020). Assessment of the Degree of Accounting for Global Sustainable Development Goals in the Strategy for Socio-Economic Development of the Rostov Region (the Russian Federation) until 2030. Economic Consultant, 29(1), 21-38. Retrieved April 3, 2020, from https://statecounsellor.wordpress.com/012020-2/

\section{INFORMATION ABOUT THE AUTHOR}

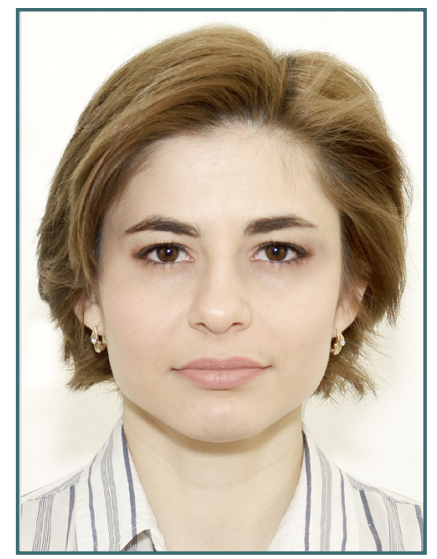

Valentina S. Vasilyeva (Russia, Rostov region) - Postgraduate student. Department of Economics of the Region, Industries and Enterprises. Rostov State Economic University. E-mail: avakyanvs@gmail.com 